http://dx.doi.org/10.18778/8088-329-1.07

Jolanta E. Kowalska, Anna Makarczuk

UNIWERSYTET ŁóDZKI

HALINA ZDEBSKA-BIZIEWSKA

InSTYTUt Nauk Spokecznych AWF Kraków

\title{
Bariery w podejmowaniu aktywności ruchowej wśród seniorów Małopolski
}

\section{Barriers to start the physical activity among seniors living in lesser Poland}

Society of our civilization is aging. People are living longer and therefore the number of older people increases thus it becomes important not only a long life, but above all, the quality of life. The quality of life which depends mainly on care for health, physical activity including their lifestyles. Physical activity is seen as one of the most important factors of human health.

This article aims at analysing the structure of physical activity among seniors living in Lesser Poland as well as the barriers of starting such activity. The research was conducted within the scope of the PolSenior nationwide programme, financed in the form of a grant by the Ministry of Science and Higher Education (ref. no. PBZ-MEIN-9/2/2006). The sample selection of respondents had a random character (of three-stage process). The study used some of the results - survey data of 157 men and 187 women of $65+$ years of age, inhabitants of the province of Lesser Poland. The results were analysed in terms of the three age groups: $65-74,75-84$ and over 85 years; of age and gender, place of residence due to the number of inhabitants (20 thousand / over 20 thousand) as well as socio - professional status (blue-collar workers / non-physical workers).

The most common barrier to start physical activity for seniors surveyed in the region are considerations of health and mental condition. 


\section{Wprowadzenie}

Proces starzenia zależy w dużym stopniu od tego w jaki sposób człowiek odnajdzie się w nowych rolach życiowych. Jakie będzie jego miejsce w rodzinie i jakie postawy wobec ludzi starych panują w społeczeństwie, w którym żyją (Jaczewski, 2005). Może w tym pomóc podejmowanie aktywności ruchowej, bo jak piszą H. Kuński i M. Janiszewski; „głównymi celami aktywności ruchowej osób starszych jest zachowanie: sprawności, samodzielności i niezależności" (Kuński, Janiszewski, 1999, s. 227).

We współczesnym społeczeństwie jakość życia uzależniona jest przede wszystkim od dbałości o zdrowie, w tym od stylu życia. Aktywność ruchowa jest postrzegana jako jeden z ważniejszych czynników zdrowia człowieka. Wielu autorów podkreśla korzyści płynące z aktywności ruchowej osób starszych, do których należy między innymi przeciwdziałanie postępującym procesom inwolucji, chorobom cywilizacyjnym, sprzyjanie aktywności społecznej. Jest również przyjemnym sposobem spędzania czasu wolnego w gronie innych osób, stanowiąc przy tym skuteczne antidotum na samotność. Jak wskazują liczne badania (Kozłowski, Nazar, 1996) aktywność ruchowa i uprawianie sportu na miarę sił i możliwości danej jednostki, decydują o sprawności psychofizycznej i wydolności fizycznej na starość a jak pisze Zofia Żukowska: „Wychodząc z założenia, że człowiek stanowi jednostkę psychofizyczną, a te dwie struktury holistycznie pojętej osobowości warunkują się w swoim rozwoju i konkretnych jego społecznych okolicznościach, to kultura fizyczna jest sferą szczególną dla aktywności ludzi III wieku" (Żukowska, 2012, s. 106).

Zdrowotne walory aktywności ruchowej, podkreślane przez wielu badaczy, są niezaprzeczalne. Jak pisał przed wiekami Wojciech Oczko: „Ruch jest w stanie zastąpić prawie każdy lek, ale wszystkie leki razem wzięte nie zastąpią ruchu" (Wikicytaty, 2010). Mimo to wiele osób, zwłaszcza starszych, niechętnie sięga po to „lekarstwo". Dlaczego tak się dzieje? Jakie czynniki wpływają negatywnie na próby podejmowania wysiłku fizycznego? Są to pytania podstawowe, na które znalezienie odpowiedzi jest tym ważniejsze, im szybciej zachodzą w naszym kraju i Europie niekorzystne zmiany demograficzne polegające na ciągłym i wzrastającym tempie starzenia się społeczeństw (Ciura, Szymańczak, 2012). A to właśnie zwiększenie aktywności ruchowej w starszym wieku - w najprostszych formach, takich jak spacery - przyczynia się do poprawy wydolności organizmu, a przez to zapobiega lub wspomaga leczenie wielu chorób (Jaczewski, 2005).

Wśród licznych analiz aktywności osób starszych nie brakuje też odniesień do aksjologicznego kontekstu tej działalności (Zdebska, 2012). Zwykle sytuuje się ją w kręgu wartości instrumentalnych, gdzie wysiłek fizyczny musi być podejmowany w konkretnym celu, w tym przypadku - dla zachowania zdrowia. Zdrowie stanowi bowiem w sensie jednostkowym i społecznym jedną z nadrzędnych wartości (przynajmniej w sferze deklaracji). Tymczasem nie mniej istotne (szczególnie w sferze motywacji) stają się wartości autoteliczne, wykraczające znacznie poza sferę troski o zdrowie. Równie ważne są kwestie związane z odczuwaniem przyjemności, pasji oraz radości, jaką niesie ruch i aktywny wypoczynek. 
Według Kwileckiej i Kunickiego (1978), bariery rekreacji fizycznej mają swoje źródło w czynnikach kulturowych, ekonomicznych, intelektualnych oraz psychicznych.

Bariery kulturowe są uważane za jeden z głównych, czasem nawet podstawowy czynnik o olbrzymim znaczeniu i wpływie na popularność kultury fizycznej, a zwłaszcza rekreacji w społeczeństwie. Historycznie ukształtowane postawy oraz poglądy, funkcjonujące przekonania i stereotypy o znaczeniu aktywności ruchowej w życiu ludzkim - wszystko to w polskich warunkach tworzy wyjątkowo niekorzystną dla rekreacji kompozycję. W naszej kulturze brak tradycji sprzyjających uczestnictwu w kulturze fizycznej jest rażący, a otaczająca ją od stuleci atmosfera niechęci nadal się utrzymuje.

„Utożsamianie aktywności fizycznej po pracy z pracą fizyczną - traktowaną jako pośledniejsza, zniewalająca, mało godna człowieka forma aktywności - stało się źródłem negatywnych nastawień do czynnego wypoczynku, przesłanką preferowania biernego spędzania czasu wolnego. I choć obecnie stanowiska takie spotyka się coraz rzadziej, to jednak przeobrażenia świadomości zbiorowej w dalszym ciągu są niedostateczne i nie nadążają za wymogami stawianymi przez współczesne warunki życia" (Winiarski, 1995, s. 25). Nikt dziś nie neguje konieczności ćwiczeń fizycznych w przypadku sportowca, a solidny trening uważa się powszechnie za niezbędny warunek sukcesu. Nikogo też nie dziwi ani nie oburza widok biegnącego wokół stadionu zawodnika. A jeszcze nie tak dawno trenujący sportowiec wzbudzał sensacje, stając się przedmiotem kpin i żartów. Zmienia się więc mentalność, totalna negacja potrzeby ćwiczeń cielesnych (przynajmniej w odniesieniu do niektórych zawodów i czynności) zdaje się ustępować miejsca bardziej racjonalnym ocenom. Ale zmiany te są jeszcze zbyt powolne, zwłaszcza w mniejszych miejscowościach i na wsi. Jest paradoksem, że więcej tolerancji wykazujemy wobec pijanego mężczyzny na ulicy niż wobec ubranej w strój sportowy, biegającej po parku kobiety.

Pokonywanie tych właśnie barier jest sprawą bardzo trudną, gdyż wymaga długotrwałego, systematycznego oddziaływania na ludzką świadomość, eliminowania starych nawyków i przyzwyczajeń oraz zastępowania ich nowymi. Muszą to być działania daleko wykraczające poza ramy tej tylko bariery i wiązać się z przełamywaniem innych ograniczeń. Tylko takie zabiegi mogą zwielokrotnić efektywność poczynań w zakresie popularyzacji kultury fizycznej i aktywnego ruchowo stylu życia.

Stan zdrowia wpływa w istotny sposób na możliwości korzystania z pewnych form aktywności. Zalecane wysiłki fizyczne można podzielić na: wytrzymałościowe, siłowe i szybkościowe - z możliwością wszelkich kombinacji. Najbardziej wskazane dla osób starszych to długotrwałe, wykonywane w średnim tempie, ruchy cykliczne o umiarkowanym charakterze, jak: chód, trucht, pływanie, jazda na rowerze oraz specjalne ćwiczenia gimnastyczne utrzymujące lub poprawiające ruchomość w stawach kończyn i kręgosłupa. Pozostałe formy - oprócz wpływu ogólnie usprawniającego - są przyjemnym sposobem spędzania wolnego czasu w towarzystwie - kulturalną formą wypoczynku i rozrywki (Kowalska, Kaźmierczak, 2009). 


\section{Metodologia badań}

Badania zostały wykonane w ramach ogólnopolskiego programu PolSenior, sfinansowanego jako grant przez Ministerstwo Nauki i Szkolnictwa Wyższego (nr PBZ-MEIN-9/2/2006). Szczegółowe opisy projektu i metod doboru prób zostały zamieszczone w pracy Błędowskiego (Błędowski i in., 2011). Badania wykonał w latach 2007-2010 specjalnie przeszkolony zespół pielęgniarek z Pracowni Badań Społecznych BGA w Sopocie. Koordynatorem projektu był Instytut Biologii Molekularnej i Komórkowej w Warszawie.

Dobór respondentów miał charakter losowy, trzystopniowy. W pracy wykorzystano część uzyskanych wyników - dane ankietowe 157 mężczyzn i 187 kobiet po 65 roku życia, mieszkańców województwa małopolskiego. Wyniki analizowano w kategoriach trzech grup wiekowych: 65-74, 75-84 i powyżej 85, lat, oraz płci, wielkości miejsca zamieszkania ze względu na liczbę mieszkańców (do 20 tys. i powyżej 20 tys.) i statusu społeczno-zawodowego (pracownicy fizyczni i niepracujący fizycznie).

Celem badań jest analiza aktywności ruchowej osób starszych z województwa małopolskiego w aspekcie wyżej wymienionych kategorii. Wyniki badań zostały przedstawione w postaci wartości odsetkowych.

W pracy sformułowano następujące pytania badawcze:

1. Jakie rodzaje aktywności ruchowej najczęściej podejmują badani seniorzy?

Czy i jakie różnice w aktywności ruchowej seniorów występują ze względu na:

- płeć badanych,

- wiek badanych,

- status społeczno-ekonomiczny,

- miejsce zamieszkania z uwzględnieniem liczby mieszkańców.

2. Jakie bariery decydują o tym, że badani seniorzy nie podejmują aktywności ruchowej?

Czy i jakie różnice w aktywności ruchowej seniorów (z uwzględnieniem powyższych aspektów), występują ze względu na:

- płeć badanych,

- wiek badanych,

- status społeczno-ekonomiczny,

- miejsce zamieszkania z uwzględnieniem liczby mieszkańców.

\section{Wyniki badań}

\section{Najczęściej podejmowane przez badanych seniorów rodzaje aktywno- ści ruchowej}

Badani seniorzy najczęściej wymieniali krótkie spacery w pobliżu miejsca zamieszkania, jako formę aktywności ruchowej podejmowaną kilka razy w tygodniu lub częściej - ogółem 73,3\% wskazań (tabela 1). Interesujące jest to, iż 
wraz z upływem lat badanych tendencja ta zmniejsza się u kobiet, a w najstarszej grupie, tj. osób powyżej 85 roku życia deklarację tę podtrzymuje tylko 62,4\% mężczyzn i 33,4\% kobiet, które częściej niż mężczyźni wskazywały (54,8\%) na podejmowane spacery mniej niż raz w miesiącu - w tym wcale. Częściej aktywność tego typu - kilka razy w tygodniu - wybierały osoby niepracujące fizycznie $(79,1 \%)$, w tym $80,8 \%$ kobiet i $74,7 \%$ mężczyzn w porównaniu z pracownikami fizycznymi (68,0\%), w tym 63,1\% kobiet i 74,5\% mężczyzn. Wielkość miejsca zamieszkania nie różnicowała badanych.

Tabela 1. Krótkie spacery w okolicach domu podejmowane przez badanych seniorów w aspekcie wieku, płci, miejsca zamieszkania i statusu społeczno-zawodowego

\begin{tabular}{|c|c|c|c|c|c|c|c|}
\hline \multirow{3}{*}{ Czynnik } & \multirow{3}{*}{ Kategoria } & \multirow{3}{*}{ Płeć } & \multicolumn{5}{|c|}{$\begin{array}{c}\text { Krótkie spacery w okolicach domu podejmowane } \\
\text { przez seniorów }\end{array}$} \\
\hline & & & \multirow{2}{*}{$\begin{array}{c}\text { mniej niż } 1 \text { raz } \\
\text { w miesiącu } \\
\text { - w tym wcale }\end{array}$} & \multirow{2}{*}{$\begin{array}{c}\text { od } 1 \text { raz } \\
\text { w miesiącu } \\
\text { do } 1 \text { raz } \\
\text { w tygodniu } \\
\%\end{array}$} & \multirow{2}{*}{$\begin{array}{c}\text { kilka razy } \\
\text { w tygodniu } \\
\text { lub częściej }\end{array}$} & \multicolumn{2}{|c|}{ ogółem } \\
\hline & & & & & & $\mathbf{N}$ & $\%$ \\
\hline \multirow{12}{*}{$\begin{array}{l}\text { Wiek } \\
\text { [lata] }\end{array}$} & $65-74$ & mężczyźni & 21,3 & 4,2 & 74,5 & 65 & 100 \\
\hline & & kobiety & 16,1 & 5,8 & 78,1 & 81 & 100 \\
\hline & & ogółem & 17,9 & 5,3 & 76,8 & 146 & 100 \\
\hline & $75-84$ & mężczyźni & 15,7 & 8,6 & 75,8 & 61 & 100 \\
\hline & & kobiety & 22,1 & 8,4 & 69,5 & 57 & 100 \\
\hline & & ogółem & 19,9 & 8,4 & 71,7 & 118 & 100 \\
\hline & $>85$ & mężczyźni & 37,6 & 0,0 & 62,4 & 30 & 100 \\
\hline & & kobiety & 54,8 & 11,9 & 33,4 & 48 & 100 \\
\hline & & ogółem & 51,6 & 9,6 & 38,8 & 78 & 100 \\
\hline & ogółem & mężczyźni & 20,0 & 5,5 & 74,5 & 156 & 100 \\
\hline & & kobiety & 20,3 & 7,0 & 72,7 & 186 & 100 \\
\hline & & ogółem & 20,2 & 6,5 & 73,3 & 342 & 100 \\
\hline \multirow{6}{*}{$\begin{array}{l}\text { Wielkość } \\
\text { miejscowości } \\
\text { [liczba miesz- } \\
\text { kańców] }\end{array}$} & do 20 tys. & mężczyźni & 20,9 & 0,0 & 79,1 & 76 & 100 \\
\hline & & kobiety & 25,6 & 3,7 & 70,7 & 109 & 100 \\
\hline & & ogółem & 24,1 & 2,6 & 73,3 & 185 & 100 \\
\hline & powyżej & mężczyźni & 19,2 & 9,9 & 70,9 & 80 & 100 \\
\hline & 20 tys. & kobiety & 14,6 & 10,6 & 74,8 & 77 & 100 \\
\hline & & ogółem & 16,4 & 10,3 & 73,3 & 157 & 100 \\
\hline \multirow{6}{*}{$\begin{array}{l}\text { Status } \\
\text { społeczno- } \\
\text { zawodowy }\end{array}$} & pracownik & mężczyźni & 20,1 & 5,4 & 74,5 & 96 & 100 \\
\hline & fizyczny, & kobiety & 25,6 & 11,3 & 63,1 & 88 & 100 \\
\hline & rolnik & ogółem & 23,2 & 8,8 & 68,0 & 184 & 100 \\
\hline & niepra- & mężczyźni & 19,8 & 5,5 & 74,7 & 60 & 100 \\
\hline & cujący & kobiety & 15,0 & 4,1 & 80,8 & 91 & 100 \\
\hline & fizycznie & ogółem & 16,4 & 4,5 & 79,1 & 151 & 100 \\
\hline
\end{tabular}

Źródło: wyniki badań wykonanych przez Pracownię Badań Społecznych BGA z Sopotu w latach 2007-2010 w ramach projektu PolSenior.

Dłuższe spacery (kilkugodzinne), piesze wycieczki na dalsze odległości od domu lub miejsca pobytu, bez względu na wiek, płeć, wielkość zamieszkiwanej miejscowości i status społeczny były najczęściej wskazywane, jako te, które są podejmowane mniej niż raz w miesiącu, w tym wcale - tabela 2. 
Tabela 2. Kilkugodzinne spacery, piesze wycieczki w dalszej odległości od domu lub miejsca pobytu podejmowane przez badanych seniorów w aspekcie wieku, płci, miejsca zamieszkania i statusu społeczno-zawodowego

\begin{tabular}{|c|c|c|c|c|c|c|c|}
\hline \multirow{3}{*}{ Czynnik } & \multirow{3}{*}{ Kategorie } & \multirow{3}{*}{ Płeć } & \multicolumn{5}{|c|}{$\begin{array}{l}\text { Kilkugodzinne spacery, piesze wycieczki } \\
\text { w dalszej odległości od domu lub miejsca pobytu } \\
\text { podejmowane przez seniorów }\end{array}$} \\
\hline & & & \multirow{2}{*}{$\begin{array}{c}\text { mniej niż } 1 \text { raz } \\
\text { w miesiącu - } \\
\text { w tym wcale } \\
\%\end{array}$} & \multirow{2}{*}{$\begin{array}{c}\text { od } 1 \text { raz } \\
\text { w miesiącu } \\
\text { do } 1 \\
\text { raz w tygo- } \\
\text { dniu } \\
\%\end{array}$} & \multirow{2}{*}{$\begin{array}{c}\text { kilka razy } \\
\text { w tygodniu } \\
\text { lub częściej }\end{array}$} & \multicolumn{2}{|c|}{ ogółem } \\
\hline & & & & & & $\mathbf{N}$ & $\%$ \\
\hline \multirow{12}{*}{$\begin{array}{l}\text { Wiek } \\
\text { [lata] }\end{array}$} & 65-74 & mężczyźni & 63,8 & 31,1 & 5,1 & 65 & \begin{tabular}{|l|}
100 \\
\end{tabular} \\
\hline & & kobiety & 65,6 & 25,2 & 9,2 & 81 & 100 \\
\hline & & ogółem & 65,0 & 27,3 & 7,7 & 146 & 100 \\
\hline & 75-84 & mężczyźni & 68,0 & 15,5 & 16,4 & 61 & 100 \\
\hline & & kobiety & 86,0 & 10,1 & 3,9 & 57 & 100 \\
\hline & & ogółem & 79,7 & 12,0 & 8,3 & 118 & 100 \\
\hline & $>85$ & mężczyźni & 85,9 & 11,8 & 2,3 & 30 & 100 \\
\hline & & kobiety & 97,9 & 2,1 & 0,0 & 49 & 100 \\
\hline & & ogółem & 95,7 & 3,9 & 0,4 & 79 & 100 \\
\hline & ogółem & mężczyźni & 65,7 & 25,7 & 8,5 & 156 & 100 \\
\hline & & kobiety & 73,9 & 19,1 & 7,0 & 187 & 100 \\
\hline & & ogółem & 71,1 & 21,4 & 7,5 & 343 & 100 \\
\hline \multirow{6}{*}{$\begin{array}{l}\text { Wielkość } \\
\text { miejscowości } \\
\text { [liczba miesz- } \\
\text { kańców] }\end{array}$} & do 20 tys. & mężczyźni & 64,6 & 30,0 & 5,4 & 76 & 100 \\
\hline & & kobiety & 71,2 & 18,6 & 10,1 & 109 & 100 \\
\hline & & ogółem & 69,2 & 22,2 & 8,6 & 185 & 100 \\
\hline & powyżej & mężczyźni & 66,7 & 22,2 & 11,1 & 80 & 100 \\
\hline & 20 tys. & kobiety & 76,9 & 19,5 & 3,6 & 78 & 100 \\
\hline & & ogółem & 73,0 & 20,6 & 6,4 & 158 & 100 \\
\hline \multirow{6}{*}{$\begin{array}{l}\text { Status } \\
\text { społeczno- } \\
\text { zawodowy }\end{array}$} & pracownik & mężczyźni & 70,4 & 22,7 & 6,9 & 96 & 100 \\
\hline & fizyczny, & kobiety & 77,1 & 13,9 & 9,0 & 88 & 100 \\
\hline & rolnik & ogółem & 74,1 & 17,8 & 8,1 & 184 & 100 \\
\hline & niepra- & mężczyźni & 58,8 & 30,2 & 11,1 & 60 & 100 \\
\hline & cujący & kobiety & 70,7 & 24,3 & 5,0 & 92 & 100 \\
\hline & fizycznie & ogółem & 67,4 & 25,9 & 6,7 & 152 & 100 \\
\hline
\end{tabular}

Źródło: wyniki badań wykonanych przez Pracownię Badań Społecznych BGA z Sopotu w latach 2007-2010 w ramach projektu PolSenior.

\section{Bariery w podejmowaniu aktywności fizycznej przez badanych seniorów}

W badaniach przeanalizowano kwestię powodów, dla których seniorzy nie podejmują aktywności ruchowej. Jako główną barierę badani podawali przeciwwskazania zdrowotne. Ponad $11 \%$ ogółu mężczyzn i prawie $14 \%$ kobiet wybrało tę odpowiedź. Jest to czynnik, który wyraźnie wzrasta wraz z wiekiem badanych (tabela 3). W grupie najmłodszej wskazało na niego około $9 \%$ ankietowanych, a w najstarszej ponad $40 \%$ (w tym prawie $50 \%$ kobiet). Częściej powód ten podają mieszkańcy mniejszych miejscowości (18,5\%) oraz pracownicy fizyczni $(18,7 \%)$, bez względu na płeć. 
Tabela 3. Bariery zdrowotne w podejmowaniu aktywności ruchowej przez badanych seniorów w aspekcie wieku, płci, miejsca zamieszkania i statusu społeczno-zawodowego

\begin{tabular}{|c|c|c|c|c|c|c|c|}
\hline \multirow{3}{*}{ Czynnik } & \multirow{3}{*}{ Kategorie } & \multirow{3}{*}{ Płeć } & \multicolumn{5}{|c|}{ Nie pozwala mi na to stan zdrowia } \\
\hline & & & \multirow{2}{*}{$\begin{array}{c}\text { nie } \\
\%\end{array}$} & \multirow{2}{*}{$\begin{array}{l}\text { tak } \\
\%\end{array}$} & \multirow{2}{*}{$\begin{array}{c}\begin{array}{l}\text { osoby podejmujące } \\
\text { aktywność fizyczną }\end{array} \\
\%\end{array}$} & \multicolumn{2}{|c|}{ ogółem } \\
\hline & & & & & & $\mathbf{N}$ & $\%$ \\
\hline \multirow{12}{*}{$\begin{array}{l}\text { Wiek } \\
\text { [lata] }\end{array}$} & $65-74$ & mężczyźni & 0,0 & 11,1 & 88,9 & 65 & 100 \\
\hline & & kobiety & 3,7 & 8,1 & 88,2 & 81 & 100 \\
\hline & & ogółem & 2,4 & 9,2 & 88,4 & 146 & 100 \\
\hline & $75-84$ & mężczyźni & 2,0 & 11,5 & 86,6 & 62 & 100 \\
\hline & & kobiety & 3,2 & 18,2 & 78,6 & 56 & 100 \\
\hline & & ogółem & 2,8 & 15,8 & 81,4 & 118 & 100 \\
\hline & $>85$ & mężczyźni & 3,5 & 25,8 & 70,7 & 30 & 100 \\
\hline & & kobiety & 4,5 & 49,1 & 46,4 & 49 & 100 \\
\hline & & ogółem & 4,3 & 44,8 & 50,8 & 70 & 100 \\
\hline & ogółem & mężczyźni & 0,7 & 11,6 & 87,7 & 157 & 100 \\
\hline & & kobiety & 3,6 & 13,8 & 82,6 & 186 & 100 \\
\hline & & ogółem & 2,6 & 13,0 & 84,4 & 343 & 100 \\
\hline \multirow{6}{*}{$\begin{array}{l}\text { Wielkość } \\
\text { miejscowości } \\
\text { [liczba miesz- } \\
\text { kańców] }\end{array}$} & do 20 tys. & mężczyźni & 0,7 & 15,0 & 84,3 & 77 & 100 \\
\hline & & kobiety & 4,2 & 20,1 & 75,7 & 109 & 100 \\
\hline & & ogółem & 3,1 & 18,5 & 78,4 & 186 & 100 \\
\hline & powyżej & mężczyźni & 0,7 & 8,8 & 90,5 & 80 & 100 \\
\hline & 20 tys. & kobiety & 2,9 & 6,9 & 90,2 & 77 & 100 \\
\hline & & ogółem & 2,1 & 7,6 & 90,3 & 157 & 100 \\
\hline \multirow{6}{*}{$\begin{array}{l}\text { Status } \\
\text { społeczno- } \\
\text { zawodowy }\end{array}$} & pracownik & mężczyźni & 0,5 & 15,1 & 84,3 & 97 & 100 \\
\hline & fizyczny, & kobiety & 3,6 & 21,5 & 74,9 & 87 & 100 \\
\hline & rolnik & ogółem & 2,2 & 18,7 & 79,0 & 184 & 100 \\
\hline & Niepra- & mężczyźni & 1,0 & 6,3 & 92,7 & 60 & 100 \\
\hline & cujący & kobiety & 2,7 & 7,4 & 89,9 & 92 & 100 \\
\hline & fizycznie & ogółem & 2,2 & 7,1 & 90,7 & 152 & 100 \\
\hline
\end{tabular}

Źródło: wyniki badań wykonanych przez Pracownię Badań Społecznych BGA z Sopotu w latach 2007-2010 w ramach projektu PolSenior.

Drugą, najczęściej wskazywaną przez ankietowanych barierę, stanowią względy psychiczne - brak odczuwania potrzeby ruchu. Odpowiedziało tak około $3 \%$ ogółu badanych (tabela 4). Częściej są to kobiety (4\%) niż mężczyźni (tylko $0,7 \%)$. Wpływ na taki stan rzeczy mogą mieć różne czynniki, np. nawyki wyniesione z młodości, stan zdrowia, samopoczucie. Nieodczuwanie potrzeby ruchu wzrasta wraz z wiekiem badanych: w grupie 65-74-latków odpowiedzi takiej nie wybrał żaden mężczyzna i tylko 3\% kobiet. Wśród najstarszych seniorów odsetki te kształtowały się odpowiednio: 3,5\% wśród mężczyzn i 8,7\% wśród kobiet. Częściej też deklarowali ją mieszkańcy małych miejscowości $(5,6 \%$ w stosunku do $0,1 \%$ z obszarów miejskich) oraz osoby pracujące fizycznie (3,4\% do $0,6 \%$ wśród niepracujących fizycznie). 
Tabela 4. Bariery psychiczne (brak odczuwania potrzeby) w podejmowaniu aktywności ruchowej przez badanych seniorów w aspekcie wieku, płci, miejsca zamieszkania i statusu społeczno-zawodowego

\begin{tabular}{|c|c|c|c|c|c|c|c|}
\hline \multirow{2}{*}{ Czynnik } & \multirow{2}{*}{ Kategoria } & \multirow{2}{*}{ Płeć } & \multirow{2}{*}{$\begin{array}{c}\text { Nie } \\
\%\end{array}$} & \multirow{2}{*}{$\begin{array}{c}\text { Tak } \\
\%\end{array}$} & \multirow{2}{*}{$\begin{array}{c}\begin{array}{l}\text { Osoby podejmujące } \\
\text { aktywność fizyczną }\end{array} \\
\% \\
\end{array}$} & \multicolumn{2}{|c|}{ ogółem } \\
\hline & & & & & & $\mathbf{N}$ & $\%$ \\
\hline \multirow{12}{*}{$\begin{array}{l}\text { Wiek } \\
\text { [lata] }\end{array}$} & $65-74$ & mężczyźni & 11,1 & 0,0 & 88,9 & 65 & 100 \\
\hline & & kobiety & 8,6 & 3,2 & 88,2 & 81 & 100 \\
\hline & & ogółem & 9,5 & 2,1 & 88,4 & 146 & 100 \\
\hline & $75-84$ & mężczyźni & 11,5 & 1,9 & 86,6 & 62 & 100 \\
\hline & & kobiety & 16,7 & 4,7 & 78,6 & 56 & 100 \\
\hline & & ogółem & 14,8 & 3,7 & 81,4 & 118 & 100 \\
\hline & $>85$ & mężczyźni & 25,8 & 3,5 & 70,7 & 30 & 100 \\
\hline & & kobiety & 44,9 & 8,7 & 46,4 & 49 & 100 \\
\hline & & ogółem & 41,4 & 7,8 & 50,8 & 70 & 100 \\
\hline & ogółem & mężczyźni & 11,6 & 0,7 & 87,7 & 157 & 100 \\
\hline & & kobiety & 13,4 & 4,0 & 82,6 & 186 & 100 \\
\hline & & ogółem & 12,8 & 2,9 & 84,4 & 343 & 100 \\
\hline \multirow{6}{*}{$\begin{array}{l}\text { Wielkość } \\
\text { miejscowości } \\
\text { [liczba miesz- } \\
\text { kańców] }\end{array}$} & do 20 tys. & mężczyźni & 14,2 & 1,5 & 84,3 & 77 & 100 \\
\hline & & kobiety & 16,7 & 7,5 & 75,7 & 109 & 100 \\
\hline & & ogółem & 15,9 & 5,6 & 78,4 & 186 & 100 \\
\hline & powyżej & mężczyźni & 9,5 & 0,0 & 90,5 & 80 & 100 \\
\hline & 20 tys. & kobiety & 9,7 & 0,2 & 90,2 & 77 & 100 \\
\hline & & ogółem & 9,6 & 0,1 & 90,3 & 157 & 100 \\
\hline \multirow{6}{*}{\begin{tabular}{|l|} 
Status \\
społeczno-za- \\
wodowy
\end{tabular}} & pracownik & mężczyźni & 14,5 & 1,2 & 84,3 & 97 & 100 \\
\hline & fizyczny, & kobiety & 19,9 & 5,1 & 74,9 & 87 & 100 \\
\hline & rolnik & ogółem & 17,6 & 3,4 & 79,0 & 184 & 100 \\
\hline & niepra- & mężczyźni & 7,3 & 0,0 & 92,7 & 60 & 100 \\
\hline & cujący & kobiety & 9,3 & 0,8 & 89,9 & 92 & 100 \\
\hline & fizycznie & ogółem & 8,7 & 0,6 & 90,7 & 152 & 100 \\
\hline
\end{tabular}

Źródło: wyniki badań wykonanych przez Pracownię Badań Społecznych BGA z Sopotu w latach 2007-2010 w ramach projektu PolSenior.

\section{Dyskusja}

Z przeprowadzonych badań wynika, że najczęściej podejmowaną przez seniorów formą aktywności ruchowej są krótkie spacery w pobliżu miejsca zamieszkania. Podobne wyniki badań uzyskali: Ignasiak i in. (2013), Stachura i in. (2008), Nowak i Doupona (2000), Parnicka (2004) badająca sposoby spędzania czasu wolnego przez kobiety.

W niniejszych badaniach główną barierę w podejmowaniu aktywności ruchowej przez osoby starsze stanowią przeciwwskazania zdrowotne. Czynnik ten nasila się wraz z wiekiem ankietowanych. Drugim powodem niepodejmowania aktywności ruchowej są względy natury psychicznej, tj. brak odczuwania potrzeby ruchu.

O braku odczuwania potrzeby ruchu przez osoby starsze pisał już na początku lat 90. XX wieku Łobożewicz (1991). Jest to czynnik, który pojawia się wielokrotnie w badaniach różnych autorów. 
Wasilewicz i współpracownicy (2013) wskazują na trzy główne bariery w podejmowaniu aktywności fizycznej przez osoby starsze (2013). Są to: słaba sprawność $(40 \%)$, problemy ze zdrowiem (30\%) oraz lęk przed ośmieszeniem $(17 \%)$.

Podobne czynniki ograniczające aktywność fizyczną seniorów z terenu województwa pomorskiego wykazali w swych badaniach Łysak i współpracownicy (2014). Podkreślili, że dominującą barierą jest zły stan zdrowia ankietowanych pomorzan oraz niechęć do podejmowania wysiłku fizycznego.

W badaniach seniorów z Dolnego Śląska (Ignasiak i in. 2013), dyskomfort zdrowotny - jako barierę ograniczającą aktywność ruchową - wymienia aż $75 \%$ respondentów w grupach młodszych wiekiem. Częściej są to mężczyźni niż kobiety.

Potwierdzeniem tych obserwacji są wnioski, jakie sformułowali Dąbrowski i Rowiński na podstawie badań wśród grupy 4813 seniorów w Polsce, zrealizowanych w ramach ogólnopolskiego projektu PolSenior (Mossakowska, Więcek, Błędowski, 2012). Wśród barier ograniczających aktywność fizyczną blisko 75\% osób nieaktywnych wymieniło zły stan zdrowia, uniemożliwiający podejmowanie aktywności ruchowej. Przyczynę tę podał co drugi badany w wieku 65-69 lat oraz ponad $90 \%$ osób wieku ponad 90 lat. Prawie co trzeci badany nie odczuwał potrzeby uczestnictwa w aktywności ruchowej. Bariera finansowa była istotna jedynie dla około $6 \%$ ankietowanych. Kobiety częściej aniżeli mężczyźni wskazywały na zły stan zdrowia. Podobnie jak u wielu innych badaczy, także i tutaj stopień odczuwania potrzeby ruchu i aktywności fizycznej zmniejszał się wraz z wiekiem badanych.

Tematyką związaną z motywami oraz barierami w podejmowaniu aktywności fizycznej zajmowali się w swoich badaniach Baj-Korpak i współpracownicy (2013). Przeprowadzili oni sondaż wśród 110 kobiet w wieku 56-65 lat. Ankietowane w większości były mieszkankami Białej Podlaskiej. Czynnikiem najczęściej wskazywanym przez badane seniorki, jako ograniczający ich aktywność ruchową, była niechęć do podejmowania wysiłku fizycznego, duża ilość atrakcyjnych zajęć o charakterze sedenteryjnym, takich jak: czytanie książek, słuchanie muzyki, spotkania towarzyskie. Ankietowane wskazywały często także na brak odpowiedniej infrastruktury do uprawiania zajęć ruchowych przez osoby starsze.

Osobowościowe i społeczno-kulturowe determinanty aktywności fizycznej ludzi starszych stanowiły też przedmiot refleksji Z. Żukowskiej (2012), podkreślającej jej biologiczne uwarunkowania (wiek i płeć). Z punktu widzenia psychicznego rozwoju jednostki, za ważkie uznaje takie czynniki, jak: poczucie własnej efektywności, kompetencje w przedmiocie aktywności fizycznej, motywacje do aktywnego trybu życia oraz satysfakcję z uczestnictwa w różnych formach aktywności ruchowej. Z czynników natury środowiskowej autorka podkreśla rolę rodziny, a na drugim miejscu - dobrze prowadzone i ciekawe lekcje wychowania fizycznego i zajęcia pozalekcyjne, w których - w młodości - uczestniczyły starsze osoby. Czynniki te mają istotny wpływ na postawy prozdrowotne prezentowane przez całe życie jednostki.

Podkreślić należy fakt, iż wśród licznych przeszkód utrudniających ludziom starszym czynne uczestnictwo w kulturze fizycznej wielu gerontologów wymienia tzw. „stereotyp starego człowieka” (Dąbrowska, Skrzek 2014). Starość 
w świadomości społecznej postrzegana jest jako spadek sił fizycznych i psychicznych, stan schorowania i ułomności oraz często niezdolności do samodzielnego życia. Przełamanie takiego stereotypu wydaje się bardzo trudne, a we współczesnej dobie starzenia się społeczeństw Europy jest konieczne.

\section{Wnioski}

Przeprowadzona analiza wyników badań ankietowych pozwala na sformułowanie następujących wniosków:

1. Badani seniorzy wskazywali na krótkie spacery w pobliżu miejsca zamieszkania jako formę aktywności ruchowej podejmowaną kilka razy w tygodniu lub częściej, wraz z upływem wieku badanych tendencja ta zmniejsza się u kobiet. Kilka razy w tygodniu tę formę aktywności wybierały najczęściej osoby niepracujące fizycznie.

2. Barierami w podejmowaniu aktywności ruchowej przez osoby starsze najczęściej są względy natury zdrowotnej oraz psychicznej. Zjawiska te nasilają się wyraźnie wraz z wiekiem badanych. Mniejsze znaczenie ma tutaj status społeczny seniorów oraz miejsce zamieszkania.

3. Niniejsze badania potwierdzają rolę wieku w podejmowaniu aktywności ruchowej przez seniorów. W najstarszej grupie badanych odsetek osób aktywnych fizycznie jest najniższy.

\section{Literatura}

Bledowski P. i wsp. 2011, Medical, psychological and socioeconomic aspects of aging in Poland Assumptions and objectives of the PolSenior Project, Exp. Gerontol. doi:10.1016/j.exger. 2011.09.006.

Baj-Korpak J., Różański P., Soroka A., Wysokińska E., 2013, Motywy i bariery uczestnictwa osób starszych w rekreacji ruchowej, „Rozprawy Społeczne”, t. VII, nr 1, s 125-136.

Dąbrowska G., Skrzek A., 2014, Kultura fizyczna ludzi starszych, na stronie: Uniwersytet Trzeciego Wieku http://www.utwstrzelin.pl/?page_id=50 (aktualizowana 31.01.2014).

Ignasiak Z., Sławińska T., Dąbrowski A., Rowiński R., 2013, The structure of physical activity in seniors from Lower Silesia, „Roczniki Państwowych Zakładów Higieny”, t. 64(1).

Jaczewski A. (red.), 2005, Biologiczne i medyczne podstawy rozwoju i wychowania, Wydawnictwo Akademickie „Żak”, Warszawa.

Kowalska J.E., Kaźmierczak A., 2009, Rola kultury fizycznej w zaspakajaniu potrzeb człowieka nowoczesnego na przykładzie słuchaczy Uniwersytetu Trzeciego Wieku, (w:) Z. Dziubiński, K.W. Jankowski (red.), Kultura fizyczna w społeczeństwie nowoczesnym, Warszawa.

Kozłowski S., Nazar K., 1996, Wprowadzenie do fizjologii klinicznej, PZWL, Warszawa.

Kuński H., Janiszewski M., 1999, Medycyna aktywności ruchowej dla pedagogów, Wydawnictwo UŁ, Łódź, s. 227.

Kwilecka M., Kunicki B., 1978, Ścieżka zdrowia - poradnik dla organizatorów i użytkowników, Warszawa.

Łobożewicz T., 1991, Stan i uwarunkowania aktywności ruchowej ludzi w starszym wieku w Polsce, Z Warsztatów Badawczych, nr 208, Wydawnictwo AWF, Warszawa. 
Łysak A., Walentukiewicz A., Drabik J., Dąbrowski A., Rowiński R., 2014, Aktywność fizyczna i niektóre jej uwarunkowania w populacji seniorów województwa pomorskiego, „Hygeia Public Health”, vol. 49 (3), s. 549-553.

Mossakowska M., Więcek A., Błędowski P. (red.), 2012, Aspekty medyczne, psychologiczne, socjologiczne i ekonomiczne starzenia się ludzi w Polsce. Raport z badań realizowanych $w$ ramach projektu PolSenior, koordynator MIBMiK, Warszawa, s. 531-548.

Nowak M., Doupona M., 2000, Formy aktywności ruchowej preferowane przez kobiety i mężczyzn, (w:) D. Umiastowska (red.), Aktywność ruchowa ludzi w różnym wieku, PTNKF, Wydawnictwo Albatros, Szczecin.

Parnicka U., 2004, Miejsce aktywności ruchowej w strukturze innych zajęć czasu wolnego kobiet, (w:) D. Umiastowska (red.), Aktywność ruchowa ludzi w różnym wieku, PTNKF, Wydawnictwo Albatros, Szczecin.

Stachura A., Płatek Ł., Benek A., 2008, Aktywność ruchowa kobiet i mężczyzn w różnym wieku, (w:) A. Kaźmierczak i wsp. (red.), Kultura fizyczna i zdrowotna współczesnego człowieka, Wydawnictwo UŁ, Łódź.

Wasilewicz W., Napierała M., Cieślicka M., Muszkieta R., Zukow W., Karaskova V., 2013, Aktywność kobiet po siedemdziesiątym roku życia, „Journal of Health Sciences”, vol. 3 (16), s. 125-134.

Winiarski R., 1995, Psychospołeczne aspekty rekreacji ruchowej, (w:) Sport dla wszystkich. Rekreacja dla każdego, cz. II, Wydawnictwo TKKF, Warszawa, s. 23-55.

Zdebska H., 2012, Aksjologiczny wymiar aktywności fizycznej w grupie wiekowej 50+, (w:) J. Nowocień, K. Zuchora (red.), Aktywność fizyczna i społeczna osób trzeciego wieku, Wydawnictwo AWF, Warszawa.

Żukowska Z., 2012, Osobowościowe i społeczno-kulturowe uwarunkowania aktywności fizycznej ludzi trzeciego wieku, (w:) J. Nowocień, K. Zuchora (red.), Aktywność fizyczna i społeczna osób trzeciego wieku, Wydawnictwo AWF, Warszawa, s. 89-107.

\section{Źródła internetowe}

Ciura G., Szymańczak J., Starzenie się społeczeństwa polskiego, Infos - Biuro Analiz Sejmowych, nr 12 (126), 2012.

http://orka.sejm.gov.pl/WydBAS.nsf/0/D5E35E200F187640C1257A29004A756B/\$file/Infos_126.pdf (aktualizowana 05.09.2014).

Dąbrowska G., Skrzek A., 2014, Kultura fizyczna ludzi starszych, na stronie: Uniwersytet Trzeciego Wieku http://www.utwstrzelin.pl/?page_id=50 (aktualizowana 31.01.2014).

https://pl.wikiquote.org/wiki/Wojciech_Oczko (aktualizowana 03.05.2010).

Kozłowski S., Nazar K., 1996, Wprowadzenie do fizjologii klinicznej, PZWL, Warszawa.

Rocznik Demograficzny GUS, 8.11.2013 www.stat.gov.pl/gus (aktualizowana 15.12.2013). 